\title{
Development and Validation of a Simple RP-HPLC Method for Simultaneous Estimation of Metformin Hydrochloride and Rosiglitazone in Pharmaceutical Dosage Forms
}

\author{
Md. Akteruzzaman², Asma Rahman², Md. Zakir Sultan², Farhana Islam³, \\ Md. Abdus Salam ${ }^{1}$ and Mohammad A. Rashid ${ }^{3}$ \\ ${ }^{1}$ Department of Chemistry, University of Dhaka, Dhaka-1000, Bangladesh. \\ ${ }^{2}$ Centre for Advanced Research in Sciences (CARS), University of Dhaka, Dhaka-1000, Bangladesh. \\ ${ }^{3}$ Department of Pharmaceutical Chemistry, Faculty of Pharmacy, University of Dhaka, \\ Dhaka-1000, Bangladesh
}

\begin{abstract}
The objective of this study was to develop a simple, efficient, precise and accurate reversed phase HPLC (RP-HPLC) method for simultaneous determination of metformin in combination with rosiglitazone in newly formulated tablets. The combination of these drugs are commonly used and prescribed as anti-diabetic drugs in Bangladesh. The method has been developed by using the mobile phase comprising of sodium dihydrogen phosphate $\left(\mathrm{NaH}_{2} \mathrm{PO}_{4}\right)$ buffer ( $\left.\mathrm{pH} 3.5\right)$ and acetonitrile $(60: 40, \mathrm{v} / \mathrm{v})$ at a flow rate of $0.7 \mathrm{ml} / \mathrm{min}$ over $\mathrm{C}_{18}$ bonded silica column (ODS) $(250 \times 4.6 \mathrm{~mm}, 5 \mu)$ at ambient temperature. The effluents were monitored at $230 \mathrm{~nm}$ and retention times were found to be $3.35 \mathrm{~min}$ and $11.95 \mathrm{~min}$ for metformin and rosiglitazone, respectively. Calibration curves were determined with a range from 0.03125 to $0.50 \mu \mathrm{mole} / \mathrm{ml}$ of standards and the regression coefficients $\left(\mathrm{r}^{2}\right)$ were found as 0.999 for metformin and 1.0 for rosiglitazone. The assay was validated for the accuracy, precision etc. according to ICH, USP and FDA guidelines. The proposed method can be useful in routine analysis for quantitative determination of metformin hydrochloride and rosiglitazone in pharmaceutical dosage forms.
\end{abstract}

Key words: HPLC, metformin hydrochloride, rosiglitazone, formulated tablet.

\section{INTRODUCTION}

Metformin (MET) is a drug of biguanide group. Chemically it is (N, $N$-dimethyl imidodicarbonimidic diamide). MET is also used in the treatment of type 2 diabetes mellitus. It improves hepatic and peripheral tissue sensitivity to insulin without the problem of serious lactic acidosis ${ }^{1-6}$. Rosiglitazone (ROSI) is used as an anti-diabetic drug. Chemically it is 5-[4(2-[methyl(pyridin-2-yl)amino]ethoxy)benzyl]-thiazolidine-2,4-dione. It acts by activation of the intracellular receptor class of the peroxisome activated receptors (PPARS). ${ }^{1,7-10}$ Many patients suffering from type 2 diabetes require treatment with more than one anti-hyperglycemic drug to achieve optimal glycemic control. Therefore, both of these

Correspondence to: Mohammad A. Rashid

Tel.: +88-02-9661900-73, Extn. - 8137

Fax: +88-02-8615583;

E-mail: rashidma@du.ac.bd

Dhaka Univ. J. Pharm. Sci. 11(2): 157-163, 2012 (December) drugs are frequently prescribed for concomitant use. $^{11,12}$ For this reason, it is necessary to have a rapid and easy method for simultaneous analysis and quantitative evaluation of these drugs in pharmaceutical dosage forms. A number of methods for individual determination of MET and ROSI have been reported in literature. ${ }^{13-23}$ A very few papers described the simultaneous analysis of MET and ROSI. $^{24}$ However, none of these methods are free from limitations. Most of the methods used for individual analysis of MET or ROSI were complex and expensive. Therefore, development of a simple HPLC method for the estimation of MET and ROSI is highly desirable. The aim of the present study was to develop a new rapid RP-HPLC method for simultaneous quantification of combination drug MET and ROSI in pharmaceutical preparations and to validate that method according to ICH, USP and FDA guidelines. ${ }^{25-31}$ 


\section{MATERIALS AND METHODS}

Drugs and reagents. Working standards of MET and ROSI with a potency of 99.29 and $99.65 \%$, respectively were collected from ACI Pharmaceuticals Ltd., Dhaka, Bangladesh. Sodium dihydrogen phosphate buffer $\left(\mathrm{NaH}_{2} \mathrm{PO}_{4}\right)$, HPLC grade acetonitrile and methanol were purchased from Active Fine Chemicals Ltd., Dhaka, Bangladesh.

Instrumentation. High Performance Liquid Chromatographic system (Shimadzu-UFLC Prominence), equipped with an auto sampler (ModelSIL 20AC HT) and UV-Visible detector (Model-SPD 20A) was used for the analysis. The data was recorded using LC-solutions software. Phenomenex $\mathrm{C}_{18}(4.6 \mathrm{~mm}$ x $250 \mathrm{~mm} ; 5 \mu \mathrm{m})$ column was used for the analysis.

Preparation of mobile phase. To prepare buffer solution of $\mathrm{pH} 3.5$, sodium dihydrogen phosphate $\left(\mathrm{NaH}_{2} \mathrm{PO}_{4}\right)$ (195.5 mg) was taken in a $1000 \mathrm{ml}$ volumetric flask. About $500 \mathrm{ml}$ of double distilled water was added into the flask, dissolved the salt and finally water was added up to the mark. Then $\mathrm{pH}$ was adjusted to 3.5 by adding dilute phosphoric acid. The mixture was sonicated for 10 minutes and then filtered through a $0.22 \mu \mathrm{m}$ millipore filter. HPLC grade actonitrile was also filtered and degassed before use into the HPLC system.

Preparation of standard stock solution. Standard solutions of the pure drugs were prepared separately by dissolving $16.68 \mathrm{mg}$ metformin $\mathrm{HCl}$ (MW of metformin $\mathrm{HCl}=165.63$, potency $=99.29 \%$ ) powder equivalent to $100 \mu$ mole MET and 35.868 $\mathrm{mg}$ rosiglitazone (MW 357.428, potency $=99.65 \%$ ) powder equivalent to $100 \mu$ mole ROSI in each 100 $\mathrm{mL}$ volumetric flask. The drugs were dissolved in aqueous methanol (50:50, v/v) and final volume was made up to the mark of each of the volumetric flask with the same solvent to get the concentration of 1.0 $\mu \mathrm{mole} / \mathrm{mL}$.

Preparation of sample solution. Ten tablets were weighed and powdered. The powders equivalent to $25.61 \mathrm{mg}$ of MET and $0.133 \mathrm{mg}$ of ROSI were taken in a $100 \mathrm{ml}$ volumetric flask. The drugs were dissolved in about $50 \mathrm{ml}$ aqueous methanol (50:50 $\mathrm{v} / \mathrm{v}$ ) and the volume was made up to the mark with same solvent. $5 \mathrm{ml}$ of this solution was further diluted to $25 \mathrm{ml}$ with same solvent to get the concentration of $1.0 \mu \mathrm{mole} / \mathrm{ml}$ and $0.003707 \mu \mathrm{mole} / \mathrm{ml}$ for MET and ROSI, respectively. Appropriate volumes of these solutions were further diluted with mobile phase to get different concentrations.

Chromatographic conditions. For simultaneous determination of MET and ROSI by RP-HPLC method, the mobile phase was comprised of sodium dihydrogen phosphate buffer $(\mathrm{pH} \quad 3.5)$ and acetonitrile in the ratio of $60: 40(\mathrm{v} / \mathrm{v})$ at a flow rate of $0.7 \mathrm{ml} / \mathrm{min}$. The injection volume was $20 \mu \mathrm{l}$ for both standard and samples. The run time was set for 15 min.

Before analysis, every standard and sample was filtered through $0.45 \mu \mathrm{m}$ filter tips. The mobile phase was also filtered, sonicated and degassed before use. The column eluate was monitored with a UV detector at $230 \mathrm{~nm}$. All analyses were done at ambient temperature under isocratic condition.

\section{Method Validation}

Specificity. The specificity of the LC method was evaluated to ensure that there was no interference from the drugs or excipients present in the pharmaceutical product. The specificity was studied by injecting the excipients and standard solutions of MET and ROSI.

Linearity. Five different solutions were prepared having concentrations of $0.03125 \mu \mathrm{mole} / \mathrm{ml}, 0.0625$ $\mu \mathrm{mole} / \mathrm{ml}, 0.125 \mu \mathrm{mole} / \mathrm{ml}, 0.25 \mu \mathrm{mole} / \mathrm{ml}$ and 0.5 $\mu \mathrm{mole} / \mathrm{ml}$ for standard by dissolving in aqueous methanol (50:50, v/v). Then $20 \mu \mathrm{l}$ from each solution was injected using auto-sampler and the analyses were monitored at $230 \mathrm{~nm}$ and repeated thrice times. The average peak areas were plotted against respective concentration. The linearity of the proposed method was evaluated by using calibration curves to calculate coefficient of correlation and intercept values.

Accuracy. The accuracy of the method is the nearness of the result obtained to the true value. The accuracy is expressed by calculating the percent recovery $(\mathrm{R} \%)$ of analyte recovered by the assay of 
spiked samples. To evaluate the accuracy of the proposed method, successive analysis $(n=3)$ for three different concentrations $(0.0125 \mu \mathrm{mole} / \mathrm{ml}$, $0.025 \mu \mathrm{mole} / \mathrm{ml}$ and $0.05 \mu \mathrm{mole} / \mathrm{ml}$ ) of standard solutions of MET and ROSI were carried out by using the proposed method.

Precision. Precision of the assay was assessed with respect to both repeatability and reproducibility. The precision of an analytical method is the degree of agreement among individual test results where the method is applied repeatedly to multiple samplings. It was checked by intra and inter-day repeatability of responses after replicate injections and expressed as RSD \% amongst responses using the formula [RSD $(\%)=($ Standard deviation/Mean $) \times 100 \%]$. In the current method development and validation protocol, precision was determined by using single concentration of $0.0125 \mu \mathrm{mole} / \mathrm{ml}, 0.025 \mu \mathrm{mole} / \mathrm{ml}$ and $0.05 \mu \mathrm{mole} / \mathrm{ml}$ for both standard solutions of MET and ROSI.

Sample analysis. To quantify the active drugs in finished pharmaceutical formulation, successive analysis $(n=3)$ of the samples of MET and ROSI were analyzed by the proposed method and the contents were determined by using the calibration curves of the standards MET and ROSI, and the formula, $\mathrm{y}=\mathrm{mx}+\mathrm{c}$.

Where, $\mathrm{y}=$ peak area of the analyzed sample, $\mathrm{m}=$ slope of the calibration curve, $\mathrm{c}=$ intercept of the calibration curve, $\mathrm{x}=$ concentration of the analyzed sample.

\section{RESULTS AND DISCUSSION}

HPLC is of one the most accurate analytical techniques used for qualitative and quantitative determinations of bulk and finished pharmaceutical products. A RP-HPLC method was developed and validated as per ICH, USP and FDA guidelines for determination of combined drugs (MET and ROSI) in pharmaceutical raw materials and finished products by using the mobile phase comprising sodium dihydrogen phosphate buffer $(\mathrm{pH} \quad 3.5)$ and acetonitrile in the ratio of $60: 40(\mathrm{v} / \mathrm{v})$ at a flow rate of $0.7 \mathrm{ml} / \mathrm{min}$. The injection volume was $20 \mu \mathrm{l}$ for both standard and samples. The two anti-diabetic drugs (MET and ROSI) were detected at $230 \mathrm{~nm}$ and at ambient temperature. The retention times of MET and ROSI were found to be $3.35 \pm 0.1 \mathrm{~min}$ and 11.95 \pm 0.1 , respectively (Figure 1 ). The specificity of the method was monitored by analyzing the placebo (containing all the ingredients of the formulation except the analyte) and a mixture solution of standards MET and ROSI. No other peak was detected close to the retention times of MET and ROSI which proved the high degree of specificity of the method (Figure 1).

When peak areas were plotted against concentration levels of $0.03125 \mu \mathrm{mole} / \mathrm{ml}, 0.0625$ $\mu \mathrm{mole} / \mathrm{ml}, 0.125 \mu \mathrm{mole} / \mathrm{ml}, 0.25 \mu \mathrm{mole} / \mathrm{ml}$ and 0.5 $\mu \mathrm{mole} / \mathrm{ml}$ of each drug, good correlation coefficients $\left(\mathrm{r}^{2}\right)$ were obtained as 0.999 for MET and 1.0 for ROSI which were within the accepted range of guidelines and represented a good linear relationship of the newly developed method. The slopes (m) and intercepts (c) of the calibration curves were found to be as 12063935 and 80476 for MET (Figure 2A) and 2923829 and -23470 for ROSI (Figure 2B), respectively.

The accuracy was evaluated at three different concentrations with spikes which were conducted in successive analysis $(\mathrm{n}=3)$ using the proposed method and the value was expressed as percentage of recovery between the mean concentrations of found and added concentration for both of these drugs. The average recoveries were found to be as $96.40 \%$, 95.84 and $97.93 \%$ for MET for the concentration levels of $0.125 \mu \mathrm{mole} / \mathrm{ml}, 0.25 \mu \mathrm{mole} / \mathrm{ml}$ and 0.5 $\mu \mathrm{mole} / \mathrm{ml}$, respectively (Table 1); and 99.84\%, 100.47 and $102.75 \%$ for ROSI for the concentration levels of $0.1255 \mu \mathrm{mole} / \mathrm{ml}, 0.2509 \mu \mathrm{mole} / \mathrm{ml}$ and $0.50185 \mu \mathrm{mole} / \mathrm{ml}$, respectively (Table 1 ).

The precision of the proposed method was checked by intraday and interday repeatability of responses after replicate injections of standard solutions of different concentrations (0.0125, 0.025, $0.05 \mu \mathrm{mole} / \mathrm{ml}$ ) three times each day for three days where RSD \% amongst responses were found as $\leq 2$ (Table 2 and 3). 
All experimental results were wihin the range of the acceptability for precision and accuracy, which indicated that the developed method was sensitive enough and accurate for qualitative, quantitative and simultaneous analysis of MET and ROSI.

The method was applied for quantitative and simultaneous analysis of combined pharmaceutical preparation of MET and ROSI formulated by local manufacturer. The quantity of active drugs was determined for three marketed preparations (sample1, sample-2 and sample-3) for each drug and the potency of MET was found to be $96.47,97.24$ and 97.54\%, respectively; where as 103.08, 102.44 and $99.68 \%$ for ROSI, respectively (Table 4).

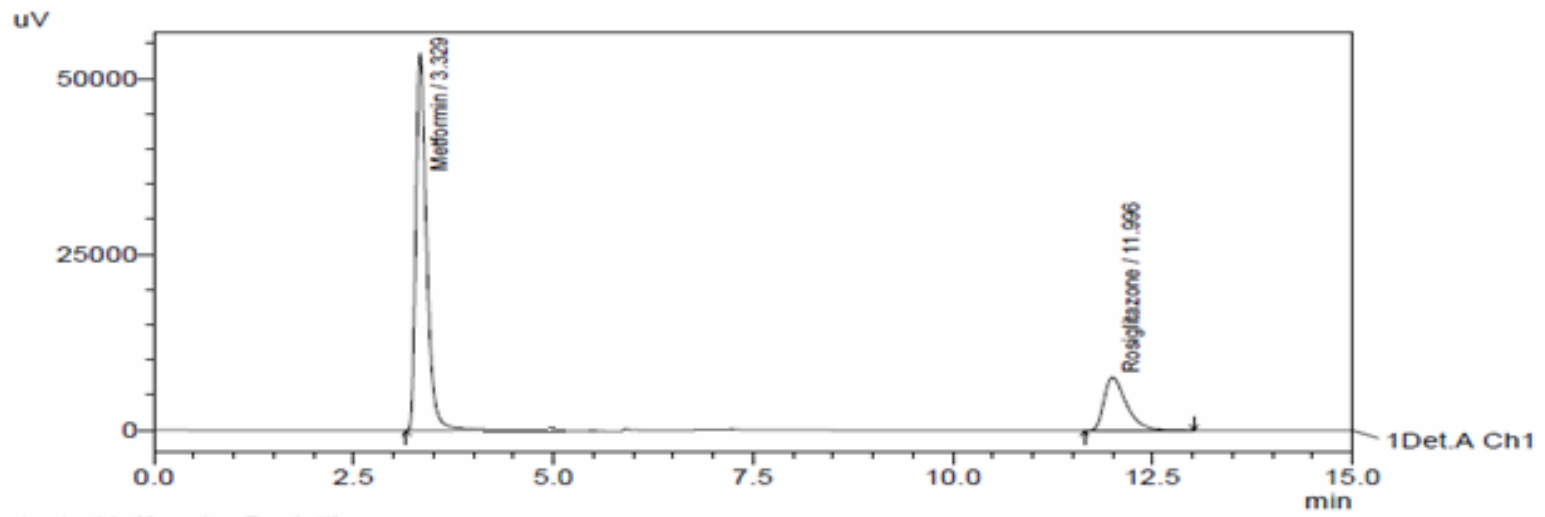

1 L-Metformin+Rosiglitazone

Figure 1. Chromatogram of MET and ROSI.
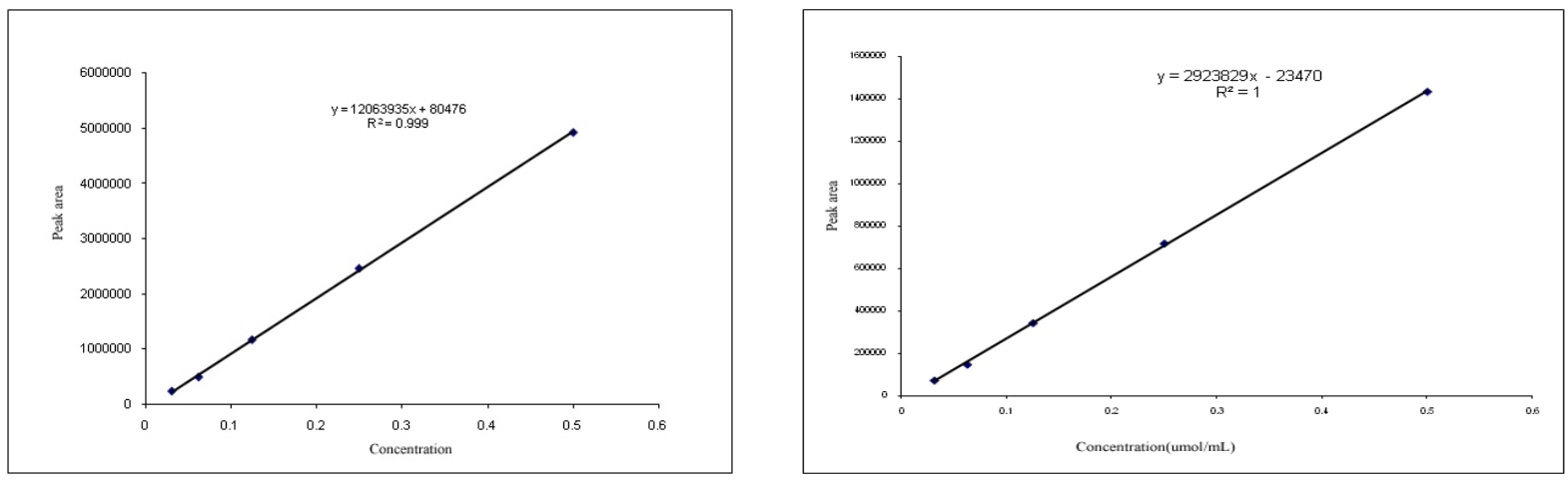

Figure 2. Calibration curves of MET and ROSI $(\mathrm{A}=\mathrm{MET}$ and $\mathrm{B}=\mathrm{ROSI})$.

Table 1. Accuracy of MET and ROSI.

\begin{tabular}{lccc}
\hline Drugs & $\begin{array}{c}\text { Injected concentration } \\
\text { Std }+ \text { Spike }(\mu \mathrm{mole} / \mathrm{ml})\end{array}$ & $\begin{array}{c}\text { Average Recovered } \\
(\mu \mathrm{mole} / \mathrm{ml})\end{array}$ & $\begin{array}{c}\text { \% Recovery }=(\text { Recovered conc./ injected } \\
\text { conc. }) \times 100\end{array}$ \\
\hline \multirow{3}{*}{ MET } & $0.125+0.0$ & 0.1205 & 96.40 \\
& $0.25+0.0$ & 0.23961 & 95.84 \\
& $0.50+0.0$ & 0.48964 & 97.93 \\
ROSI & $0.125+0.0005$ & 0.1253 & 99.84 \\
& $0.25+0.0009$ & 0.25209 & 100.47 \\
\hline
\end{tabular}


Table 2. Intraday precision of MET and ROSI.

\begin{tabular}{|c|c|c|c|c|c|}
\hline Drug & Day & Injected conc. $\mu$ mole/ml & Mean area & SD & Intraday \%RSD \\
\hline \multirow{9}{*}{ MET } & \multirow{3}{*}{ Day-1 } & 0.0125 & 232181 & 1071.974 & 0.461698 \\
\hline & & 0.025 & 381772.5 & 1129.25 & 0.295791 \\
\hline & & 0.05 & 703665.5 & 1573.313 & 0.223588 \\
\hline & \multirow{3}{*}{ Day-2 } & 0.0125 & 232990 & 1316.633 & 0.565103 \\
\hline & & 0.025 & 382640.5 & 2024.447 & 0.529073 \\
\hline & & 0.05 & 703073 & 1779.081 & 0.253044 \\
\hline & \multirow{3}{*}{ Day-3 } & 0.0125 & 226313.5 & 1704.835 & 0.75330656 \\
\hline & & 0.025 & 370640.5 & 1819.38575 & 0.490876 \\
\hline & & 0.05 & 705576 & 8851.56269 & 1.25451584 \\
\hline \multirow{9}{*}{ ROSI } & \multirow{3}{*}{ Day-1 } & 0.0125 & 13443 & 192.333 & 1.43073 \\
\hline & & 0.025 & 53156.5 & 113.8442 & 0.214168 \\
\hline & & 0.05 & 121034.5 & 1033.083 & 0.853544 \\
\hline & \multirow{3}{*}{ Day-2 } & 0.0125 & 13037.5 & 210.0107 & 1.61082 \\
\hline & & 0.025 & 51790.5 & 915.7033 & 1.768091 \\
\hline & & 0.05 & 124372.5 & 1956.564 & 1.573149 \\
\hline & \multirow{3}{*}{ Day-3 } & 0.0125 & 13496.5 & 226.98127 & 1.68178 \\
\hline & & 0.025 & 51258.5 & 317.4909 & 0.619392 \\
\hline & & 0.05 & 122838 & 1043.69 & 0.849647 \\
\hline
\end{tabular}

Table 3: Interday precision of MET and ROSI.

\begin{tabular}{|c|c|c|c|c|c|c|}
\hline Drug & Day & Injected conc. $\mu$ mole/ml & $\begin{array}{c}\text { Intraday mean } \\
\text { area }\end{array}$ & Mean & SD & $\begin{array}{c}\text { Inter-day } \\
\% R S D\end{array}$ \\
\hline \multirow{9}{*}{ MET } & Day-1 & \multirow{3}{*}{0.0125} & 232181 & \multirow{3}{*}{230494.8333} & \multirow{3}{*}{3643.663} & \multirow{3}{*}{1.5808} \\
\hline & Day-2 & & 232990 & & & \\
\hline & Day-3 & & 226313.5 & & & \\
\hline & Day-1 & \multirow{3}{*}{0.025} & 381772.5 & \multirow{3}{*}{378351.1667} & \multirow{3}{*}{6691.722} & \multirow{3}{*}{1.768654} \\
\hline & Day-2 & & 382640.5 & & & \\
\hline & Day-3 & & 370640.5 & & & \\
\hline & Day-1 & \multirow{3}{*}{0.05} & 703665.5 & \multirow{3}{*}{704104.8333} & \multirow{3}{*}{1308.057} & \multirow{3}{*}{0.185776} \\
\hline & Day-2 & & 703073 & & & \\
\hline & Day-3 & & 705576 & & & \\
\hline \multirow{9}{*}{ ROSI } & Day-1 & \multirow{3}{*}{0.0125} & 13443 & \multirow{3}{*}{13325.67} & \multirow{3}{*}{250.9892} & \multirow{3}{*}{1.883502} \\
\hline & Day-2 & & 13037.5 & & & \\
\hline & Day-3 & & 13496.5 & & & \\
\hline & Day-1 & \multirow{3}{*}{0.025} & 53156.5 & & \multirow{3}{*}{979.0628} & \multirow{3}{*}{1.880336} \\
\hline & Day-2 & & 51790.5 & 52068.5 & & \\
\hline & Day-3 & & 51258.5 & & & \\
\hline & Day-1 & \multirow{3}{*}{0.05} & 121034.5 & & \multirow{3}{*}{1670.806} & \multirow{3}{*}{1.361164} \\
\hline & Day-2 & & 124372.5 & 122748.3 & & \\
\hline & Day-3 & & 122838 & & & \\
\hline
\end{tabular}

Table 4. Sample analysis.

\begin{tabular}{ccccc}
\hline Drug & Sample Code & $\begin{array}{c}\text { Injected conc. } \\
(\mu \mathrm{mole} / \mathrm{mL})\end{array}$ & $\begin{array}{c}\text { Mean recovered } \\
(\mu \mathrm{mole} / \mathrm{ml})\end{array}$ & $\begin{array}{c}\text { Average \% Recovery }=(\text { Mean } \\
\text { recovered conc./ injected conc. }) \times 100\end{array}$ \\
\hline \multirow{3}{*}{ MET } & Sample-1 & 0.25 & 0.24117 & 96.468 \\
& Sample-2 & 0.5 & 0.48619 & 97.238 \\
& Sample-3 & 1.0 & 0.975365 & 97.5365 \\
\multirow{3}{*}{ ROSI } & Sample-1 & 0.0125 & 0.012885 & 103.08 \\
& Sample-2 & 0.025 & 0.02561 & 102.44 \\
& Sample-3 & 0.05 & 0.04984 & 99.68 \\
\hline
\end{tabular}




\section{CONCLUSION}

The validation study showed that the developed method was accurate, rapid, precise, reproducible and inexpensive with acceptable correlation co-efficient and standard deviations which make it versatile and valuable for simultaneous determination of metformin hydrochloride and rosiglitazone from pharmaceutical dosage forms, especially combined formulations. The advantages included simplicity of sample preparation and the low costs of reagents used. The proposed method was simple and did not involve laborious time-consuming sample preparation. So this HPLC method can be used in the quality control department.

\section{ACKNOWLEDGEMENTS}

The authors are thankful to ACI Pharmaceuticals Ltd., Dhaka, Bangladesh for providing reference standards and Centre for Advanced Research in Sciences (CARS) for permission as well as providing all facilities to complete this research work.

\section{REFERENCES}

1. Brunton, L. L., Lazo, J. S. and Parker K. L. 2005. Goodman \& Gilman's the pharmacological basis of therapeutics. McGraw-Hill Professional, eleventh edition, pp.1638-1639.

2. Zhou, G., Myers, R., Li, Y., Chen, Y., Shen, X., FenykMelody, J., Wu, M., Ventre, J., Doebber, T., Fujii, N., Musi, N., Hirshman, M. F., Goodyear, L. J. and Moller, D. E. 2001. Role of AMP-activated protein kinase in mechanism of metformin action. J. Clin. Invest. 108, 1167-1174.

3. Turner, R. C., Cull, C. A., Frighi, V. and Holman. R. R. 1999. Glycemic control with diet, sulfonylurea, metformin, or insulin in patients with type 2 diabetes mellitus: progressive requirement for multiple therapies (UKPDS 49). J. Am. Med. Assoc. 281, 2005-2012.

4. Garber, A. J., Duncan, T. G., Goodman, A. M., Mills, D. J. and Rohlf, J. L. 1997. Efficacy of metformin in type II diabetes: results of a double-blind, placebo-controlled, doseresponse trial. Am. J. Med. 103, 491-497.

5. Dunn, C. J. and Peters, D. H. 1995. Metformin, a review of its pharmacological properties and therapeutic use in noninsulin-dependent diabetes mellitus. Drugs 49, 721-749.

6. Kirpichnikov, D., McFarlane, S. I. and Sowers, J. R. 2002. Metformin: an update. Ann. Intern. Med. 137, 25-33.
7. Kahn, S.E., Haffner, S.M., Heise, M.A. Herman, W.H., Holman, R.R., Jones, N.P., Kravitz, B.G., Lachin, J.M., O'Neill, M.C., Zinman, B. and Viberti, G. 2006. Glycemic durability of rosiglitazone, metformin, or glyburide monotherapy. N. Engl. J. Med. 355, 2427-2443.

8. Freed, M.I., Ratner, R., Marcovina, S.M., Kreider, M.M., Biswas, N., Cohen, B.R. and Brunzell, J.D. 2002. Effects of rosiglitazone alone and in combination with atorvastatin on the metabolic abnormalities in type 2 diabetes mellitus. Am. J. Cardiol. 90, 947-952.

9. Balfour, J.A. and Plosker, G.L. 1999. Rosiglitazone. Drugs 57, 921-932.

10. Haffner, S.M., Greenberg, A S., Weston, W.M., Chen, H., Williams, K. and Freed, M.I. 2002. Effect of rosiglitazone treatment on nontraditional markers of cardiovascular disease in patients with type 2 diabetes mellitus. Circulation 106, 679-684.

11. Fryer, L.G.D., Patel A.P. and Carling, D. 2002. The antidiabetic drugs rosiglitazone and metformin stimulate ampactivated protein kinase through distinct signaling pathways. J. Bio. Chem. 277, 25226-25232.

12. Home, P.D., Pocock, S.J., Nielsen, H.B., Curtis, P.S., Gomis, R., Hanefeld, M., Jones, N.P., Komajda, M. and McMurray, J.J.V. 2009. Rosiglitazone evaluated for cardiovascular outcomes in oral agent combination therapy for type 2 diabetes (RECORD): a multicentre, randomised, open-label trial. Lancet 373, 2125 - 2135.

13. British Pharmacopoeia. The Stationary Office, MHRA British Pharmacopoeial Commission Office, London; 2005. Vol. 1.

14. Huupponen, R., Ojala, K.P., Rouru, J. and Koulu, M. 1992. Determination of metformin in plasma by high performance liquid chromatography. J. Chromatogr. B. Biomed. Sci. Appl. 583, 270-273.

15. Vasudevan, M., Ravi, J., Ravisankar, S. and Suresh, B. 2001. Ion-pair liquid chromatography technique for the estimation of metformin in its multicomponent dosage forms. J. Pharm. Biomed. Anal. 25, 77-84.

16. Porta, V., Schramm, S.G., Kano, E.K., Koono, E.E., Armando, Y. P., Fukuda, K. and Serra, C.H. dos-R. 2008. HPLC-UV determination of metformin in human plasma for application in pharmacokinetics and bioequivalence studies. J. Pharm. Biomed. Anal. 46, 143-147.

17. Fatema, K., Rahman, M.Z., Haque, T., Azad, M.A.K. and Reza, M. S. 2010. Development and validation of a simple method for simultaneous estimation of metformin hydrochloride and gliclazide in tablets by using reversed phase high performance liquid chromatography. Dhaka Univ. J. Pharm. Sci. 9, 83-89.

18. Arayne, M.S., Sultana, N. and Zuberi, M.H. 2006. Development and validation of RP-HPLC method for the analysis of metformin. Pak. J. Pharm. Sci. 19, 231-235. 
19. Hruska, M.W. and Frye, R.F. 2004. Simplified method for determination of rosiglitazone in human plasma. $J$. Chromatogr. B 803, 317-320.

20. Kolte, B.L., Raut, B.B., Deo, A.A., Bagool, M.A. and Shinde, D.B. 2003. Liquid chromatographic method for the determination of rosiglitazone in human plasma. $J$. Chromatogr. B 788 , 37-44.

21. Radhakrishna, T., Satyanarayana, J. and Satyanarayana, A. 2002. LC determination of rosiglitazone in bulk and pharmaceutical formulation. J. Pharm. Biomed. Anal. 29, 873-880.

22. Yao, J., Shi, Y.Q., Li, Z.R. and Jin, S.H. 2007. Development of a RP-HPLC method for screening potentially counterfeit anti-diabetic drugs. J. Chromatogr. B 853, 254-259.

23. Muxlow, A.M., Fowles, S. and Russell, P. 2001. Automated high-performance liquid chromatography method for the determination of rosiglitazone in human plasma. $J$. Chromatogr. B. Biomed. Sci. 752, 77-84.

24. Kolte1, B.L., Raut, B.B., Deo, A.A., Bagool, M.A. and Shinde1, D.B. 2004. Simultaneous determination of metformin in combination with rosiglitazone by reversedphase liquid chromatography. J. Chromatogr. Sci. 42, 70-73.

25. Sultan, M.Z., Huda, G.Z.U., Hossain, A., Mazid, A. and Rashid, M.A. 2012. Development and validation of a RPHPLC method for the quantification of sparfloxacin in pharmaceutical dosage forms. Ars Pharm. 53, 11-16.
26. Sultan, M.Z., Rahman, A.M., Hossain, A. and Rashid, M.A. 2011. Quantification of cephradine in pharmaceutical dosage forms formulated in Bangladesh. J. Dhaka Int. Univ. 3, 121125.

27. Sultan, M.Z., Mazid, M.A. and Rashid, M.A. 2011. Stability assessment of cephradine suspensions formulated in Bangladesh. J. Sci. Res. 3, 383-391.

28. Food and Drug Administration : Validation and verification guidance for human drug analytical methods (appendix 1), Document No.: ORA-LAB.5.4.5, Version No.: 1.6, pp. 1719, Effective Date: 10-01-03, Revised: 01-25-12; Website: http://www.fda.gov/downloads/ScienceResearch/FieldScienc e/UCM092147.pdf Date of download: 22/01/2013.

29. International Conference on Harmonisation (ICH) Harmonised Tripartite Guideline: Text on Validation of Analytical Procedures (Q2A)

30. International Conference on Harmonisation (ICH) Harmonised Tripartite Guideline: Validation of Analytical Procedures: Methodology (Q2B)

31. United States Pharmacopeia (USP) section -1225: Validation of compendial methods. 